\title{
КОМПЛЕКСНИЙ СТАТИСТИЧНИЙ АНАЛІЗ ДАНИХ МЕДИЧНИХ СПОСТЕРЕЖЕНЬ ЗА ДІТЬМИ З ГОСТРОЮ ХІРУРГІЧНОЮ ПАТОЛОГІЄЮ
}

\author{
С. В. Єгоров, Л. С. Коряшкіна' ${ }^{1}$, І. Ю. Симонець ${ }^{1}$ \\ Дз «Дніпропетровська медична академія МОз України» \\ ${ }^{1}$ Національний технічний університет «Дніпровська політехніка»
}

\begin{abstract}
Запропонована методика комплексного статистичного аналізу даних спостережень за станом дітей із хірургічною патологією двох вікових груп. Представлено результати програмної реалізації розробленого алгоритму. Виявлений терапевтичний есрект від застосування кожного з трьох лікарських засобів - розчину на основі глюкози з додаванням електролітів, кристалоїдних розчинів Рінгера лактат та малат. Наведено порівняльну характеристику дії лікарських засобів у різних вікових групах пацієнтів.
\end{abstract}

Ключові слова: перевірка гіпотез, описова статистика, розчин Рінгера, аналіз крові, прикладне програмне забезпечення.

\section{COMPREHENSIVE STATISTICAL ANALYSIS OF MEDICAL OBSERVATION DATA FOR CHILDREN WITH ACUTE SURGICAL PATHOLOGY}

\author{
S. V. Yegorov, L. S. Koriashkina ${ }^{1}$, I. Yu. Symonets ${ }^{1}$ \\ SI «Dnipropetrovsk Medical Academy of the Ministry of Health of Ukraine» \\ ${ }^{1}$ Dnipro University of Technology
}

Background. Modern information technologies provide the opportunity to apply different methods of Data Mining and statistics for analyze the huge archives of medical data, containing information about the various cases of each existing disease etc.

Purpose. The purpose of this research is developing a method for a comprehensive statistical analysis of the data of medical observations for children with acute surgical pathology to detect the influence of different infusion media used in the treatment on the clinical and laboratory parameters of the children. We compare three solutions - based on glucose with the addition of electrolytes, Ringer's lactate and Ringer's malat.

Materials and methods. Input information - results of clinical observation of 137 children with acute surgical pathology aged 6 to 17 years during consecutive five days. All patients are divided into two groups by age: $1-$ from 6 to 12 years, 2 - from 13 to 17 years, and into three categories by type of infusion solution used during treatment. The biochemical composition of urine and blood of each patient is represented by the following data: blood red blood cells, hemoglobin, leukocytes, diuresis speed, body surface area, daily diuresis, density and acetone in urine, potassium, sodium, chlorine, lactate, urea in blood, renal and cardiac enzymes, urea nitrogen, the rate of filtration of creatine in the kidneys; creatine, glucose and acidity of blood, total number of acidic and alkaline buffers in the blood, blood bicarbonate level, anionic gap, blood osmolarity, potassium, sodium content, creatine chloride in urine, sodium excretion by the kidneys. Instrumental researches have established: shock volume of heart, minute volume of blood, cardiac index, volume of external and intracellular fluid and circulating blood (\% of body weight), total peripheral resistance of vessels.

The procedure of each mentioned indicator analysis, proposed and implemented in Java language, include: a) calculating of descriptive statistics and confidence interval for each of the five observations in each patient group; b) assessing the significance of the difference in the sample mean of two observations (the first and each subsequent one) using the student's t-criterion or Wilcox's W-criterion; c) calculating the rate of indicator change and its descriptive statistics and its comparative analysis for different solutions using the Student's t-criterion (for independent samples) or the Mann-Whitney U-criterion; d) comparison of the one therapy action in the different age patients groups.

Results. It is elicited rates for which certain therapies used in treatment have a significant or almost no effect, supporting the indicator within acceptable limits. A comparative analysis of the therapy effect in different age groups and a comparison of three types of therapy among themselves are carried out. For each of the biochemical or physiological indicators, we determined moments when a certain solution starts to affect it substantially.

Conclusions. The developed application software allows you to quickly automatically perform an analysis of the effects of various types of therapy used to treat one disease, based on patient data collected over several consecutive days. Such an analysis facilitates the generation of substantiated conclusions about further therapeutic treatment.

Key words: hypothesis verification, descriptive statistics, Ringer solution, blood test, application software. 


\title{
КОМПЛЕКСНЫЙ СТАТИСТИЧЕСКИЙ АНАЛИЗ ДАННЫХ МЕДИЦИНСКОГО НАБЛЮДЕНИЯ ЗА ДЕТЬМИ С ОСТРОЙ ХИРУРГИЧЕСКОЙ ПАТОЛОГИЕЙ
}

\author{
С. В. Егоров, Л. С. Коряшкина ${ }^{1}$, И. Ю. Симонец ${ }^{1}$ \\ ГУ «Днепропетровская медицинская академия МОЗ Украины» \\ ${ }^{1}$ Национальный технический университет «Днепровская политехника»
}

Предложена методика комплексного статистического анализа данных наблюдений за состоянием детей с хирургической патологией двух возрастных групп. Представлены результаты программной реализации разработанного алгоритма. Выявлен терапевтический эфорект от применения каждого из трех лекарственных средств - раствора на основе глюкозы с добавлением электролитов, кристаллоидых растворов Рингера лактат и малат. Приведена сравнительная характеристика действия лекарственных средств в разных возрастных группах пациентов.

Ключевые слова: проверка гипотез, описательная статистика, раствор Рингера, анализ крови, прикладное программное обеспечение. 
Вступ. На даний момент важко уявити собі галузь діяльності людини, що б не зазнала впливу інформаційних технологій (IT). Учені-медики також не втрачають шансу використовувати можливості IT, адже розвиток медицини залежить від постійних медико-біологічних експериментів, аналізу ефективності лікарських засобів (ЛЗ), різноманітних як доклінічних, так і клінічних досліджень. У розпорядженні медичних закладів знаходяться колосальні архіви медичних даних, що містять відомості про різні випадки кожного існуючого захворювання, періодичності появи сезонних захворювань тощо.

Як зазначено в [1], складність медичних процесів, індивідуальність перебігу захворювань, велика кількість слабо формалізованих факторів і симптомів, що підлягають аналізу, з одного боку, та наявність досить жорстких математичних вимог до обсягу й узгодженості даних комп'ютерного аналізу, з іншого боку, призводить до необхідності виявлення прихованих зв'язків у величезних обсягах накопиченої інформації про пацієнтів. Вирішення цього завдання можливе лише на основі використання потенціалу сучасних IT, застосування автоматизованих систем, засобів інтелектуальної підтримки, орієнтованих на оброблення різнорідних (кількісних, якісних, текстових) даних.

Проблеми наукового аналізу медичних даних із використанням сучасних технологій висвітлюється в [2]. Тут представлена хронологія розвитку пакетів прикладних програм для обробки й аналізу даних на той момент. Короткий опис сучасного рівня розвитку медичної інформатики в Україні й у світі наведено в [3]. У роботі [4] визначено завдання, що необхідно виконати для розроблення уніфікованої методики математико-статистичного аналізу результатів наукових досліджень у рамках нової методології, яка базується на системному аналізі та сучасній статистичній парадигмі.

В [5] представлено широкий спектр розчинів, що застосовуються в педіатричній практиці, та обгрунтована необхідність зміни звичного рутинного застосування 5-10 \% розчину глюкози та 0,2 \% фізіологічного розчину. Зазначено, що з метою запобігання гіпонатріємії у дітей із хірургічною патологією корисним є введення ізотонічних сольових розчинів. Докладна характеристика такого найбільш поширеного електролітного порушення під час катаболічних станів у дітей, як гіпонатріємія, наведена в роботі [6].

Мета роботи: розроблення на основі системного підходу методики комплексного статистичного аналізу даних медичних спостережень за дітьми 3 гострою хірургічною патологією для виявлення впливу різних інфузійних середовищ (розчинів), що застосовуються при лікуванні, на основні клініко-лабораторних показників організму дітей, а також проведення порівняльної характеристики дії застосовуваних розчинів.

Матеріал і методи дослідження. Наведено в такій послідовності: збір і систематизація інформації, методика проведення комплексного статистичного аналізу даних медичних спостережень, обгрунтування вибору програмного забезпечення для реалізації запропонованої методики, результати аналізу даних.

Збір і систематизація інформації. Не претендуючи на повноту збору даних, за вихідну інформацію прийнято дані про результати клінічного спостереження 137 дітей віком від 6 до 17 років, які знаходилися на лікуванні у відділені інтенсивної терапії Дніпропетровської обласної дитячої клінічної лікарні з приводу гострої хірургічної патології. Пацієнтів розділено на дві групи за віком: 1 - від 6 до 12 років, 2 - від 13 до 17 років, i на три категорії за типом інфузійного розчину, що використовувався під час лікування: А - розчин на основі глюкози з додаванням електролітів, В — кристалоїдний розчин Рінгера лактат, C — збалансований кристалоїдний розчин Рінгера малат. Далі групи дітей будемо позначати: $1 \mathrm{~A}, 1 \mathrm{~B}, 1 \mathrm{C}, 2 \mathrm{~A}$, 2В, 2С. Кількість спостережень - 21, 16, 19, 32, 24, 25 відповідно.

Дані, що отримано у відділенні інтенсивної терапії, містять структурні ознаки, які, за попередньою оцінкою експертів-медиків, можуть виявитися суттєвими в завданнях підвищення якості лікування та зниження тривалості перебування в стаціонарі. Вся зібрана інформація структурована у вигляді таблиці MS Excel, що включає таку інформацію: ідентифікаційний номер досліджуваного, вік, вага, ідентифікатор групи за типом розчину та віком, тривалість перебування в реанімації, тривалість лікування в лікарні, частота дихання, частота серцевих скорочень, тиск.

Біохімічний склад сечі та крові представлено такими даними: еритроцити крові, гемоглобін, лейкоцити, швидкість діурезу, площа тіла, добового діурезу, густина сечі, ацетон у сечі, вміст калію, натрію, хлору, лактату в крові, ниркові ферменти, серцеві ферменти, сечовина в крові, азот сечовини, швидкість фільтрації креатину в нирках, креатин крові, глюкоза крові, кислотність 
крові, загальне число кислотних і лужних буферів у крові, рівень бікарбонату крові, аніонний проміжок, осмолярність крові, вміст калію, натрію, хлору креатину в сечі, виведення натрію нирками. Інструментальними методами досліджень встановлено: ударний об'єм серця, хвилинний об'єм крові, серцевий індекс, об’єми рідини (\% від маси тіла), об’єми зовнішньо- та внутрішньокліткової рідини та циркулюючої крові (\% від маси тіла), загальний периферичний опір сосудів.

Для кожного пацієнта значення вказаних параметрів зафіксовано за результатами спостережень протягом п'яти послідовних днів.

Методика проведення статистичного аналізу даних. Оскільки основною метою оброблення зібраної інформації є порівняння результатів лікування дітей за трьома типами терапії, дослідження різниці дії кожної з них, що виявляється в суттєвій (істотній) зміні певних показників аналізу крові, сечі, інших фізіологічних параметрів, запропоновано таку схему аналізу кожного із спостережуваних показників.

1. Для кожного з п'яти спостережень у кожній групі пацієнтів розраховуються такі основні статистики: максимальне та мінімальне значення, вибіркове середнє, вибіркова дисперсія, середньоквадратичне відхилення; довірчий інтервал і середня похибка вибірки.

2. Оцінюється значущість різниці вибіркових середніх двох спостережень (першого та кожного наступного) за допомогою t-критерія Стьюдента (якщо гіпотеза про рівність дисперсій не відкидається) або W-критерія Вілкоксона, якщо t-критерій Стьюдента неможливо використати. Тим самим виявляється момент, коли певний розчин починає суттєво впливати на біохімічний або фізіологічний показник. Крім того, з усіх спостережуваних показників можна вилучити ті, на які жодна терапія не впливає так, щоб їхні величини виходили за межі норми.

3. Розраховується швидкість зміни показника, її описова статистика. Здійснюється порівняльний аналіз швидкості зміни показника за рахунок дії різних розчинів, використовуючи t-критерій Стьюдента (для незалежних вибірок) або U-критерій Манна-Уітні.

4. Порівняння дії однієї терапії у різних вікових групах пацієнтів здійснюється шляхом оцінювання значущості різниці середньої швидкості зміни показника у відповідних групах за допомогою t-критерія Стьюдента (для незалежних вибірок) або U-критерія Манна-Уітні.
Обгрунтування вибору програмного забезпечення. $Є$ чимала кількість спеціалізованих статистичних програм. Одні не відрізняються особливо зовні від електронних таблиць, проте забезпечені значним арсеналом доступних статистичних прийомів. Крім того, в них традиційно потужна графічна частина (більше графіків, i більш гнучке управління ними), наявна підсистема підготовки звітів. Представником цієї групи $€$, наприклад, система STATISTICA [7]. Але, як і в усіх візуальних системах, одного разу проведене дослідження доводиться заново відтворювати, як тільки з'являються нові дані. Гнучкість пакету STATISTICA велика, але лише в межах так званих модулів. Якщо ж треба скомбінувати роботу декількох модулів, то доводиться писати складні макроси. Алгоритми обчислень у STATISTICA закриті, тому важко простежити, що саме робить програма. За кордоном широко використовуються системи SPSS та MiniTab, проте в нашій країні вони не дуже поширені.

Популярним сьогодні в світі $є$ середовище для статистичних розрахунків — пакет R. Це не тільки статистика у вузькому сенсі слова, а й «первинний» аналіз (графіки, таблиці спряженості) та просунуте математичне моделювання. Та хоча гнучкість і вільний код пакету дозволяє створювати додатки практично на будь-який випадок життя, R має й чимало недоліків, найголовніший із яких — труднощі навчання - команд багато, вводити їх потрібно вручну, а звичної системи меню немає. Тому часом дуже важко знайти, як саме зробити певний аналіз.

Для отримання результатів розрахунків різних статистик у форматі, зручному для подальшого аналізу, запропоновано алгоритм комплексного статистичного аналізу даних був реалізований об'єктно-орієнтованою мовою програмування Java, популярність якої пов'язана, насамперед, з її унікальною портативністю - програми Java працюють на будь-якому пристрої у будь-якій операційній системі. Дані з формату таблиці Excel були переведені до формату JSON за допомогою бібліотеки Gson.

Результати та їх обговорення. 1. Для всіх 42 клінічних показників і параметрів аналізу крові та сечі за кожним рядом спостережень розраховується описова статистика. При цьому для візуалізації загальної тенденції зміни показників за рахунок дії тієї чи іншої терапії середні значення показника для кожної групи спостережуваних відображаються на відповідних графіках. На координатній 
площині зазначаються також верхня і нижня межі, що вважаються нормою для показника, за для того, щоб можна було наочно простежити, які саме клінічні параметри стану пацієнта в середньому суттєво відхиляються від норми та на якому етапі. Докладно результати з описової статистики представимо лише для показників Лейкоцити та Аніонний проміжок, дії ЛЗ на які досить показові.
Так, на рис. 1 представлено формат виводу результатів описової статистики для рівня лейкоцитів для дітей першої вікової групи.

Середні значення показника по групах протягом п’яти днів відображено на рис. 2 (горизонтальні лінії - нижня та верхня норми показника).

Зміну середніх по групах значень аніонного проміжку можна простежити на рис. 3 .

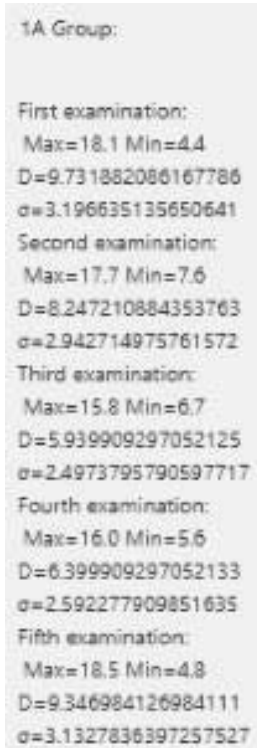

$1 B$ Grous:

First examination:

Max $=17.1$ Min $=10.8$

$D=3.6498437500000023$

o* 19731109108833533

Second axamination

Max $=16.1$ Min $=9.0$

$\mathrm{D}=5.100875000000002$

$\sigma=23339522980555985$

Third examination

$\mathrm{Max}=13.8 \mathrm{Min}=70$.

$\mathrm{D}=3.2180359374999926$

$d=1.8527344655940312$

Fourth examination:

$\mathrm{Max}=11.9 \mathrm{Min}=58$

$0=2.3190234375000145$

$q=1.5727762073566678$

Fith eramination:

Max $=10.2$ Min=3.9

$D=3.3499609374999935$

$a=1.8903152294430678$

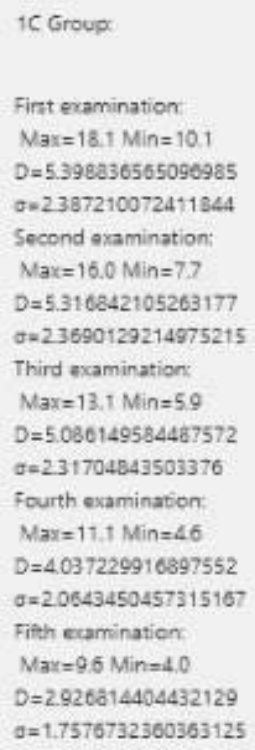

Рис. 1. Результати описової статистики для рівня лейкоцитів

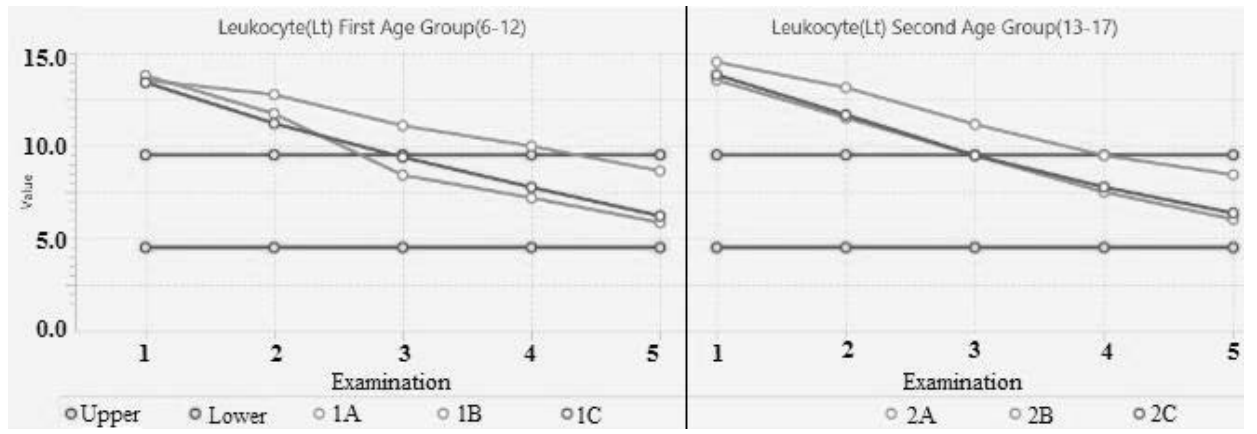

Рис. 2. Середні значення рівня лейкоцитів у дітей

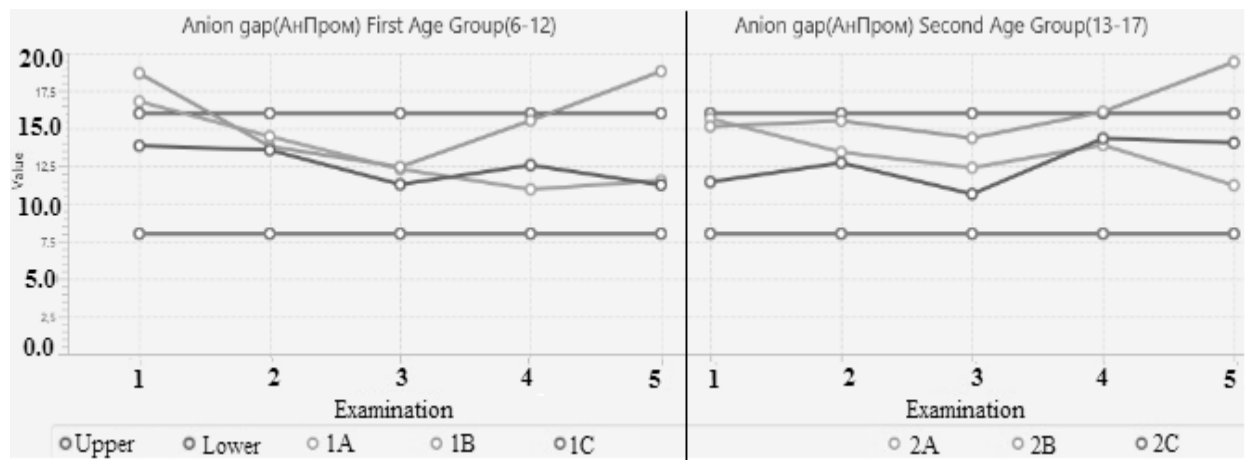

Рис. 3. Середні значення аніонного проміжку 


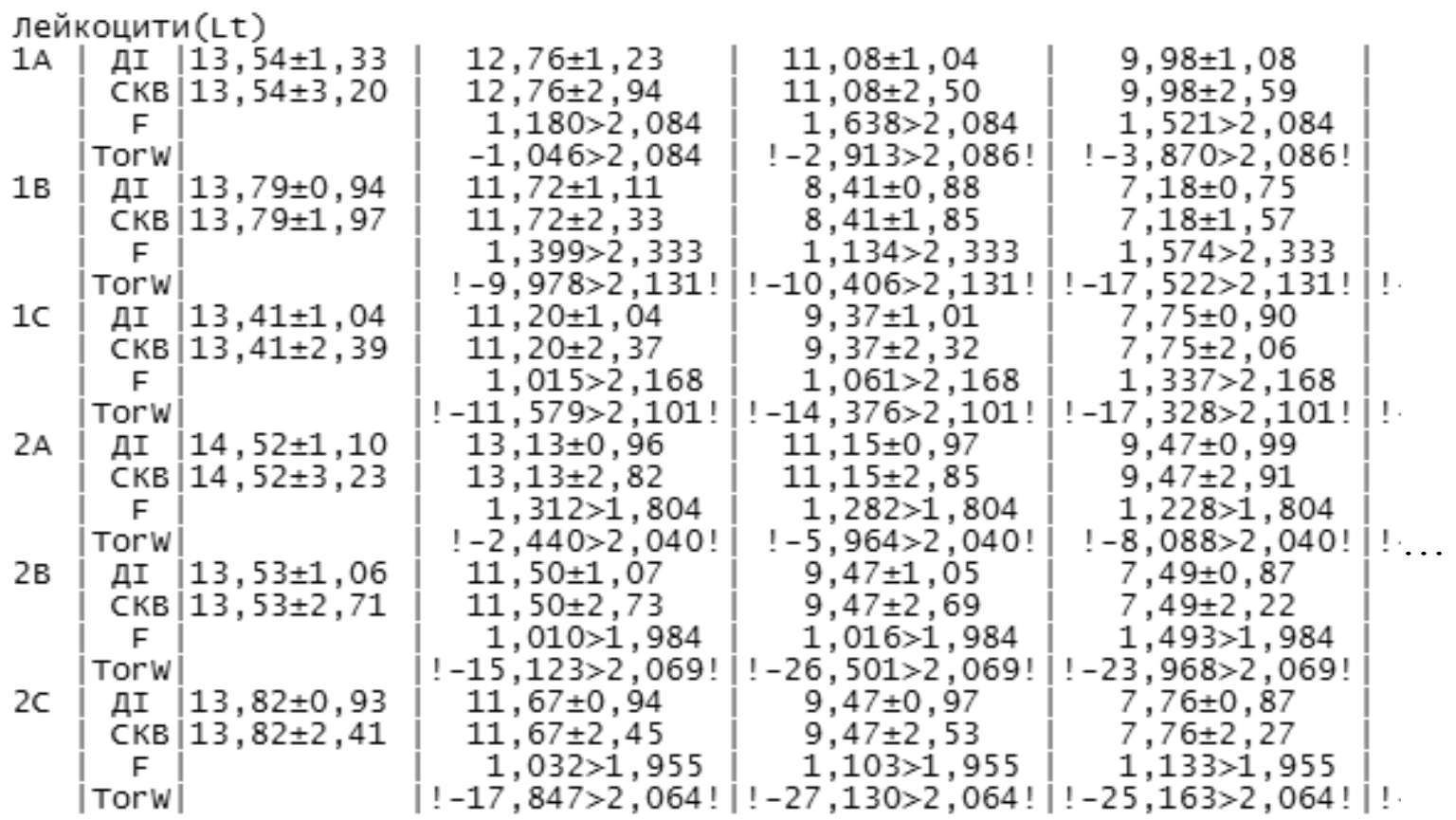

Рис. 4. Результати описової статистики та перевірки гіпотез про рівність дисперсій і середніх значень рівня лейкоцитів

Рис. 4 відображає інше представлення результатів описової статистики рівня лейкоцитів. Тут для кожної групи спостережуваних у першому рядку дані представлено у вигляді 95 \% довірчого інтервалу, тобто для кожного дня спостереження (відповідний стовпчик) зазначено $\bar{x} \pm t(\gamma, n-1) \cdot \sigma / \sqrt{n}$, де $\bar{x}$ - вибіркове середнє значення показника, $t(\gamma, n-1)$ - табличний $\gamma$-рівень надійності зі ступенями вільності $n-1, \sigma-$ вибіркове середньоквадратичне відхилення, $n-$ об'єм вибірки. В нашому випадку $\gamma=\alpha / 2$, а рівень значущості $\alpha=1-0.95=0.05$.

У другому рядку дані наведено у форматі $\bar{x} \pm \sigma$, що призначений для опису вибірок із нормальним розподілом. Перевірку типу розподілу було здійснено за критерієм узгодження Шапіро-Уілка, що є надійним, коли об'єм вибірки більше за 7 і менше або дорівнює 50, і більш потужним за інші, тому що дає найменшу ймовірність прийняти нульову гіпотезу, коли насправді є вірною альтернативна гіпотеза [8]. У даному випадку — прийняти гіпотезу про нормальний розподіл, коли розподіл не відповідає нормальному.

3 метою виявлення моменту суттєвого впливу розчину на показник аналізу крові або сечі ставиться та перевіряється гіпотеза про рівність середніх значень показника в перший день і кожного наступного дня. Спочатку за допомогою критерію Фішера перевіряється гіпотеза $\mathrm{H}_{0}: \sigma_{1}^{2}=\sigma_{2}^{2}$ про рівність дисперсій у двох вибірках за умови конкуруючої гіпотези $\mathrm{H}_{1}: \sigma_{1}^{2} \neq \sigma_{2}^{2}$.

$$
\text { Розраховується статистика } F=\frac{s_{1}^{2}}{s_{2}^{2}} \text {, де } s_{1}^{2} \text { і } s_{2}^{2}-
$$
вибіркові оцінки дисперсій для двох вибірок, що порівнюються, причому $s_{1}^{2}>s_{2}^{2}$. Якщо

$$
F>F_{\kappa p}(\alpha / 2 ; n-1 ; m-1) \text {, }
$$

де $\alpha$ - рівень значущості, $n, m-$ об'єми вибірок із більшою та меншою дисперсіями відповідно (в даному випадку, нульову гіпотезу відкидають на користь конкуруючої гіпотези, інакше - немає підстав її відкинути). В таблиці на рис. 4 у третьому рядку зазначено саме нерівність (1). Де вона порушується, там будемо вважати, що виконується умова про рівність двох дисперсій у початковій і поточній вибірках.

Значущість різниці вибіркових середніх двох спостережень (першого та поточного) була оцінена за допомогою двостороннього t-критерія Стьюдента для зв'язних вибірок (якщо гіпотеза про рівність дисперсій не відкидається) або W-критерія Вілкоксона, якщо t-критерій Стьюдента неможливо використати. При цьому розраховуються і порівнюються з критичними при рівні значущості $\alpha=0,05$ відповідні статистики (див. четвертий рядок у таблиці на рис. 4). Там, де гіпотеза $\mathrm{H}_{0}: \bar{x}_{1}=\bar{x}_{2}$, де $\bar{x}_{1}$ i $\bar{x}_{2}$ - середні значення показника в перший і поточний дні, порушується, в таблиці проставлена позначка «!» ліворуч і праворуч наведеної нерівності. 
Аналіз суттєвості зміни показників здійснено й шляхом побудови довірчих інтервалів для різниці значень показника на першому і поточному вимірах. Отримані результати досліджень за всіма 42 показниками дають змогу зробити такі висновки:

1) жодна терапія не впливає суттєво протягом усіх днів спостережень на такі показники, як: тиск (верхній, нижній, пульсовий і середній); серцеві та ниркові ферменти, сечовина крові, азот сечовини, швидкість фільтрації креатину в нирках, креатинін і хлор крові; калій, натрій і хлор у сечі. Крім того, такі параметри, як тиск, ниркові ферменти, хлор крові та сечі виявилися поза нормою менш ніж у 20 \% усіх спостережуваних;

2) усі три розчини впливають суттєво вже з перших днів лікування на такі показники: частота серцевих скорочень, лейкоцити, діурез, водний баланс, ацетон у сечі; сечовина, кислотність, хвилинний об’єм крові, серцевий індекс, відношення об’єму рідини і об’єму крові до маси тіла, загальний периферичний опір судин;

3) на решту показників розчини діють по-різному. Так, терапія, що проводиться на основі сольового або комбінованого розчину, знижує рівень еритроцитів і гемоглобіну, а перший розчин ці показники в середньому підтримує на початковому рівні. Всі три розчини знижують рівень ацетону в сечі, хоча в групах 2B і 2С на 3-й і 4-й дні спостерігається невелике його зростання. Як і очікувалося, рівень глюкози в крові підвищується в перші дні лікування з використанням відповідного розчину, терапія 3 вмістом сольового розчину майже не змінює в середньому цей параметр. Всі три розчини після третього дню лікування значно знижують ударний об’єм серця, хвилинний об’єм крові, серцевий індекс. Протягом перших двох днів усі терапії призводять до норми загальний периферичний опір судин і далі підтримують його на нормальному рівні.

2. Порівняння дії препаратів на той чи інший показник у кожній групі пацієнтів здійснюється на основі розрахованої швидкості зміни показника та ії̈ описової статистики. При цьому використовується або t-критерій Стьюдента (для незалежних вибірок) або U-критерій Манна-Уітні, якщо t-критерій Стьюдента неможна застосувати через або не підтвердження нормального розподілу хоча б однієї з малих вибірок, або відкидання гіпотези про рівність дисперсій двох нормально розподілених вибірок. У табл. 1 наведено інформацію про порівняння дії кожної пари досліджуваних розчинів у групах пацієнтів однієї вікової групи: «+» означає суттєву різницю, «-»- різниця не суттєва, тобто розчини або не впливають взагалі, або діють майже однаково.

Таблиця 1

Порівняння дії розчинів у групах одного віку

\begin{tabular}{|c|c|c|c|c|c|c|}
\hline \multirow[b]{2}{*}{ Показник } & \multicolumn{6}{|c|}{ Групи } \\
\hline & \begin{tabular}{|l|}
$1 \mathrm{~A}$ \\
та \\
1B
\end{tabular} & \begin{tabular}{|l|}
$1 \mathrm{~A}$ \\
та \\
$1 \mathrm{C}$
\end{tabular} & \begin{tabular}{|l|l|} 
1B \\
Ta \\
1C
\end{tabular} & $\begin{array}{l}2 \mathrm{~A} \\
\text { та } \\
2 \mathrm{~B}\end{array}$ & $\begin{array}{l}\mathrm{2A} \\
\mathrm{Ta} \\
2 \mathrm{C}\end{array}$ & \begin{tabular}{|l|}
$2 B$ \\
та \\
2C \\
\end{tabular} \\
\hline Частота дихання & - & - & - & - & - & - \\
\hline Частота серцевих скорочень & + & + & - & + & + & - \\
\hline Еритроцити & + & + & - & + & + & + \\
\hline Гемоглобін & + & + & - & + & + & + \\
\hline Лейкоцити & + & + & - & + & + & + \\
\hline Швидкість виділення сечі & - & - & - & + & + & - \\
\hline Добовий діурез & - & - & - & + & + & - \\
\hline Щільність сечі & - & - & - & - & - & - \\
\hline Ацетон у сечі & - & - & - & - & - & - \\
\hline Калій крові & - & - & - & + & + & - \\
\hline Натрій крові & + & + & - & + & - & - \\
\hline Лактат крові & - & - & - & + & + & + \\
\hline Глюкоза крові & - & - & - & + & + & + \\
\hline Кислотність крові & - & + & + & - & + & + \\
\hline
\end{tabular}




\section{Порівняння дії розчинів у групах одного віку}

\begin{tabular}{|c|c|c|c|c|c|c|}
\hline \multirow[b]{2}{*}{ Показник } & \multicolumn{6}{|c|}{ Групи } \\
\hline & $\begin{array}{l}\text { 1A } \\
\text { Ta } \\
1 \mathrm{~B}\end{array}$ & $\begin{array}{l}\mathbf{1 A} \\
\text { та } \\
1 \mathrm{C}\end{array}$ & $\begin{array}{l}\text { 1B } \\
\text { ra } \\
\text { 1C }\end{array}$ & $\begin{array}{l}2 \mathrm{2A} \\
\text { Ta } \\
\text { 2B }\end{array}$ & $\begin{array}{l}2 \mathrm{~A} \\
\text { та } \\
2 \mathrm{C}\end{array}$ & $\begin{array}{l}\text { 2B } \\
\text { та } \\
\text { 2C }\end{array}$ \\
\hline Загальна кількість кислотних і лужних буферів у крові & - & - & - & - & - & - \\
\hline Рівень бікарбонату крові & - & - & - & - & - & - \\
\hline Аніонний проміжок & + & - & - & + & - & - \\
\hline Осмолярность крові & + & + & - & + & - & - \\
\hline Креатинін у сечі & - & - & - & + & - & + \\
\hline Виведення натрію нирками & + & - & + & + & + & - \\
\hline Ударний об’єм серця & - & - & - & - & - & - \\
\hline Хвилинний об’єм крові & + & + & - & + & + & - \\
\hline Серцевий індекс & - & + & - & + & + & - \\
\hline Обсяг рідини від маси тіла & - & - & - & + & - & + \\
\hline Обсяг позаклітинної рідини від маси тіла & - & - & - & - & - & - \\
\hline Обсяг внутрішньоклітинної рідини & - & - & - & + & - & + \\
\hline Обсяг крові від маси тіла & + & + & - & + & + & - \\
\hline Загальний периферичний опір судин & - & - & - & - & - & - \\
\hline Кількість показників, на які розчини діють по-різному & 10 & 10 & 2 & 19 & 13 & 9 \\
\hline
\end{tabular}

Отже, аналіз табл. 1 дозволяє зробити такі висновки:

1) вплив усіх розчинів майже однаковий на такі показники, як частота дихання, щільність сечі та її ацетон, загальну кількість кислотних та лужних буферів у крові, рівень бікарбонату крові, ударний об’єм серця, обсяг позаклітинної рідини від маси тіла, загальний периферичний опір судин (що підтверджує деякі висновки попереднього пункту);

2) дія ЛЗ, що містять кристалоїдні розчини (В i C), у першій віковій групі дітей майже та сама, суттєва різниця лише в швидкості зміни двох параметрів - кислотності крові та виведення натрію нирками;

3) найменше між собою відрізняються розчини B i C;

4) на дітей старшої групи вплив розчинів більш різноманітний.

3. Аналіз різниці одного й того ж інфузійного розчину на різні вікові групи пацієнтів здійснюється також із використанням t-критерію Стьюдента або U-критерію Манна-Уітні. В табл. 2 наведено співвідношення дії розчинів у різних групах: «+» — різниця суттєва, «-» — різниця не суттєва.

Таблиця 2

\section{Порівняння дії лікарських засобів у різних вікових групах пацієнтів}

\begin{tabular}{|l|c|c|c|l|c|c|c|}
\hline \multirow{2}{*}{ Показник } & \multicolumn{2}{|c|}{ розчин } & \multicolumn{2}{c|}{ Показник } & \multicolumn{2}{c|}{ розчин } \\
\cline { 2 - 4 } & $\mathbf{A}$ & $\mathbf{B}$ & $\mathbf{C}$ & & A & B & C \\
\hline Частота дихання & - & - & - & Заг. кільк. кисл. і лужн. буф. & + & + & + \\
\hline Частота серцевих скорочень & + & + & + & Рівень бікарбонату крові & + & + & + \\
\hline Еритроцити & - & - & - & Аніонний проміжок & - & - & - \\
\hline Гемоглобін & - & - & + & Осмолярность крові & - & + & - \\
\hline Лейкоцити & - & - & + & Креатинін у сечі & - & + & - \\
\hline Швидкість виділення сечі & - & - & - & Виведення натрію нирками & - & - & - \\
\hline
\end{tabular}


Продовж. табл. 2

\section{Порівняння дії лікарських засобів у різних вікових групах пацієнтів}

\begin{tabular}{|c|c|c|c|c|c|c|c|}
\hline \multirow[t]{2}{*}{ Показник } & \multicolumn{3}{|c|}{ розчин } & \multirow[t]{2}{*}{ Показник } & \multicolumn{3}{|c|}{ розчин } \\
\hline & A & B & $\mathrm{C}$ & & A & $\mathbf{B}$ & C \\
\hline Добовий діурез & - & - & - & Ударний об’єм серця & + & + & + \\
\hline Щільність сечі & - & - & - & Хвилинний об’єм крові & + & + & + \\
\hline Ацетон у сечі & + & + & + & Серцевий індекс & + & + & + \\
\hline Калій крові & - & - & - & Обсяг рідини від маси тіла & - & - & - \\
\hline Натрій крові & - & - & - & Обсяг позакл. Рід. від маси тіла & - & - & - \\
\hline Лактат крові & + & + & - & Обсяг внутрішньокліт. & + & - & + \\
\hline Глюкоза крові & - & - & + & Обсяг крові від маси тіла & + & - & - \\
\hline Кислотність крові & + & + & - & Загальний перифер. опір судин & - & - & - \\
\hline
\end{tabular}

Отже, кількість показників, на які в різних вікових групах дітей інфузійні розчини А, В, С діють по-різному, дорівнює 8, 8, 9 відповідно.

Висновки. Отже, представлена в роботі методика комплексного аналізу даних медичних спостережень за дітьми двох вікових груп дозволяє виявити відмінність дії різних інфузійних розчинів, що використовуються при проведенні інтенсивної терапії у дітей із хірургічною патологією. Розроблене прикладне програмне забезпечення дозволяє швидко

\section{Література.}

1. Самойленко Н. Э. Комплексный анализ медицинских данных / Н. Э. Самойленко, В. Н. Кувина, С. С. Кувин // Вестник ВГТУ. - 2009. - № 9. - С. 1-5.

2. Гойко О. В. Сучасні технології обробки й аналізу медичних даних / О.В.Гойко // Медична інформатика та інженерія. - 2009. - № 4.- С. 39-44.

3. Качмар В. О. Медичні інформаційні системи - стан розвитку в Україні / В. О. Качмар // Український журнал телемедицини та медичної телематики. 2010. - Т. 8. - № 1. - С. 12-17.

4. Мунтян О. А. Пакети прикладних програм статистичного аналізу результатів наукових досліджень / О. А. Мунтян, М. Л. Мунтян, А. Г. Яровенко // Суч. інф. технології та інноваційні методики навч. у підготовці фахівців: методологія, теорія, досвід, проблеми. 3б. наук. пр. - Київ-Вінниця: Планер, 2017. - Вип. 49. - С. $135-138$.

5. Снисарь В. И. Кристаллоидные растворы у детей / В. И. Снисарь, С. В. Егоров // Біль, знеболювання і інтенсивна терапія. - 2016. - № 2. - С. 64-76.

6. Єхалов В. В. Гіпонатріємія в дітей з хірургічною патологією / В. В. Єхалов, С. В. Єгоров, О. О. Багуніна // Клінична медицина. - 2018. - Том XXIII. T. 4. - № 1. - С. 58-61. в автоматичному режимі здійснювати аналіз дії різних видів терапії, що застосовуються при лікуванні, на основі даних про стан пацієнтів, зібраних протягом декількох послідовних днів. Такий аналіз сприяє виробленню обгрунтованих рішень про подальше терапевтичне лікування.

Напрямом подальших наукових досліджень $\epsilon$ використання при аналізі подібних даних методів Data Mining, що поряд із статистичними методами відтворюють процес виявлення раніше невідомих, практично корисних закономірностей.

7. Реброва О. Ю. Статистический анализ медицинских данных. Применение пакета прикладных программ STATISTICA / O. Ю. Реброва. - М.: МедиаСфера. 2000. - 312 c.

8. Медик В. А. Статистика в медицине и биологии: Руководство. В 2-х томах / В. А. Медик, М. С. Токмачев, Б. Б. Фишман. Под ред. Ю. М. Комарова. Т. 1. Теоретическая статистика. - М.: Медицина, 2000. - 412 с.

\section{References.}

1. Samojlenko, N. E., Kuvina, V. N., Kuvin, S. S. (2009). Kompleksnyj analiz medicinskih dannyh [Comprehensive analysis of medical data]. Vestnik VGTU, 9, 1-5. [In Russian].

2. Hoiko, O. V. (2009). Suchasni tekhnolohii obrobky y analizu medychnykh danykh [Modern technologies processing and analysis of medical data]. Medychna informatyka ta inzheneriia (Medical informatics and engineering), 4, 39-44. [In Ukrainian].

3. Kachmar, V. O. (2010). Medychni informatsiini systemy - stan rozvytku v Ukraini [Medical information system - current state in Ukraine]. Ukrainskyi zhurnal telemedytsyny ta medychnoi telematyky, 8 (1), 12-17. [In Ukrainian]. 
4. Muntian, O. A., Muntian, M. L., Yarovenko, A. H. (2017). Pakety prykladnykh prohram statystychnoho analizu rezultativ naukovykh doslidzhen [Software packages for statistical analysis of research results]. Such. inf. tekhnolohii ta innovatsiini metodyky navch. u pidhotovtsi fakhivtsiv: metodolohiia, teoriia, dosvid, problemy. Zb. nauk. pr., 49, 135-138. [In Ukrainian].

5. Snisar', V. I., Egorov, S. V. (2016). Kristalloidnye rastvory u detej [Crystalloid solutions in children]. Bil, zneboliuvannia i intensyvna terapiia, 2, 64-76. [In Russian].

6. Yekhalov, V. V., Yegorov, S. V., Baguni na, O. O. (2018). Hiponatriiemiia $v$ ditei $z$ khirurhichnoiu patolohiieiu
[Hyponatremia in children with surgical pathology]. Klinychna medytsyna, XXIII, 4 (1), 58-61. [In Ukrainian].

7. Rebrova, O. Yu. (2000). Statisticheskij analiz medicinskih dannyh. Primenenie paketa prikladnyh programm STATISTICA [Statistical analysis of medical data. Application package STATISTICA]. MediaSfera. [In Russian].

8. Medik, V. A., Tokmachev, M. S., Fishman, B. B. (2000). Statistika v mediczine i biologii: Rukovodstvo. V 2-kh tomakh. [Statistics in Medicine and Biology: A Guide. In 2 volumes]. Mediczina, 1, 412. [In Russian]. 